reader can easily follow up these aspects. Chapters 12-15 provide interesting reading and reveal many important lines of research which so far have received far from adequate attention. Thus, it still remains to be shown whether a flowering hormone actually exists, and there is much to be discovered about naturally occurring growth inhibitors. Taken as a whole, the book can be said to serve the needs of all who are interested in this field of work. Certainly, the physiological approach is useful and stimulating to the chemist, and the physiologist likewise will find the chemical treatment satisfying. Yet the book is most readable and the aim of the author to cater for the layman as well as the scientist has been quite well achieved, there being a useful glossary of technical terms for those completely new to this field of study.

The volume is well produced with excellent photographs and diagrams. Many references to original work are given, and appendixes relating to the use of specific compounds for the rooting of cuttings, the setting of fruit, weed control and for preventing the pre-harvest drop of apples are provided.

This book is the best of its kind yet published and can be confidently recommended. R. L. WArN

\section{SEEING THROUGH THE ATMOSPHERE}

Vision through the Atmosphere

By W. E. Knowles Middleton.

xiv +250 Oxford University Press, 1952.) 68s. net.

HIS book replaces the author's well-known
earlier and smaller volume, "Visibility in
Meteorology", the second edition of which appeared
in 1941. It is in no sense a third edition but an
entirely new book, although most of the ground
covered is the same as before. The reason for the
change of title is interesting. As the author points
out, "To the meteorologist 'the visibility' means a
distance-that at which it is just possible to dis-
tinguish a dark object against the horizon. It is now
fourteen years since the writer began to press for a
change in this illogical terminology, and his complete
lack of success is probably only an indication that
language is born, not made". The book is concerned
with a much wider field than 'visibility' in this
restricted sense; in fact, it deals with what have
been well termed the photometric properties of
the atmosphere and their measurement, and with
those properties of the eye which affect the visual
range.

The author is at pains to drive home his thesis that the present method of estimating 'visibility' is completely out of date, since it ignores most of the great volume of work carried out by physicists and others during the Second World War. This work makes it possible to predict with remarkable accuracy the range at which a given object can be detected, provided we know certain physical quantities concerning the atmosphere, quantities which can now be readily measured with fairly simple photometric apparatus.

The underlying theory is described in detail in two chapters. These are followed by a short chapter on the eye, and then come the chapters in which all that has gone before is synthesized and in which methods are described for determining the visual range of objects seen in daylight and light sources seen at night. There is also a chapter on the colours of distant objects and the visual range of coloured objects. The last main chapter consists of descriptions, most often with diagrams, of instruments used for measuring the quantities related to visual range. Of these the chief are extinction and scatter. Many different types of telephotometers used for measuring extinction are described and criticized and then a section is devoted to instruments which measure scatter. 'Visibility meters' are not ignored.

It is gratifying to note the evident and expressed appreciation of the author for the work carried out in Britain during the War. Incidentally, as an index of the stimulus which the War supplied, it is notable that of the 420 papers listed by the author in his bibliography, nearly one-half date from 1940 onwards.

"Visibility in Meteorology" was a classic, and to say that the present volume is a worthy successor is no mean praise, but it is fully justified. The subjectmatter is not easy ; but the exposition is clear and the style is excellent, while here and there are welcome touches which reveal the author's sense of humour. The production is very good and the lavish use of paper such as to cause a jealous pang to many a publisher and author in Britain. A British reader may regret the use of American terms, such as 'phototube' for 'photocell', and some other unfamiliar words such as 'illuminance' for 'illumination', while on p. 7 there is the misleading statement that the International Commission on Illumination has adopted the term 'luminance factor' for both 'luminous reflectance' and 'luminous transmittance'. The very minor nature of these criticisms, however, only serves to indicate the high standard which the author has set himself and has achieved in a book which will be highly valued, not only by meteorologists, but also by others who are interested in the subject indicated by the title. JoHN W. T. WALSH

\section{JEAN REY'S PIONEER WORK ON OXIDATION}

\section{The Essays of Jean Rey}

A facsimile reprint of the original edition of 1630 . With an introduction by Dr. Douglas McKie. Pp. xliv + 144+xlv-lxxxiii. (London : Edward Arnold and Co., Ltd. 1951.) 21s. net.

EAN REY was a French physician, born at $\mathrm{L}_{\theta}$ Bugue, a small town near Perigueux, in Dordogne, where he practised after graduating M.D. in the University of Montpellier in 1609. His claim to fame is that he anticipated, by some hundred and fifty years, Lavoisier's conclusion, first announced in 1774 , that the increase in weight in metals on calcination is due to their combination with air. Rey; however, did not visualize combination in the sense proposed by Lavoisier and accepted to-day. His views were supported by one experiment only; but by means of this experiment he claimed, to use his own words, that "all opinions contrary to mine are utterly refuted". He discussed the effects of calcination in a little book entitled "Essays . . . sur la recerche de la cause pour laquelle l'Estain \& le Plomb augmentent de poids quand on les calcine", which was printed at Bazas, near Bordeaux, in 1630. In 1775, immediately following the publication 